\title{
Influence of habitat configuration on connectivity between fish assemblages of Caribbean seagrass beds, mangroves and coral reefs
}

\author{
M. Dorenbosch ${ }^{1, *}$, W. C. E. P. Verberk ${ }^{1,2}$, I. Nagelkerken $^{1}$, G. van der Velde Vel $^{1,3}$ \\ ${ }^{1}$ Department of Animal Ecology and Ecophysiology, Institute for Water and Wetland Research, Faculty of Science, and \\ ${ }^{2}$ Bargerveen Foundation, Radboud University Nijmegen, PO Box 9010, 6500 GL Nijmegen, The Netherlands \\ ${ }^{3}$ National Museum of Natural History Naturalis, PO Box 9517, 2300 RA Leiden, The Netherlands
}

\begin{abstract}
The importance of seagrass beds and mangroves as juvenile habitats for coral reef fishes is still debatable. We hypothesised that the configuration of these habitats in the marine landscape in relation to the coral reef would influence accessibility from the reef (both for fishes that use these habitats for shelter or feeding, and their predators). In combination with differences in habitat complexity (related to habitat type) this could influence the utilisation of these habitats by juvenile reef fishes, and connectivity with the coral reef. Using underwater visual census, we studied the use by juvenile reef fishes of various seagrass and mangrove habitats situated differently in relation to the coral reef, on the Caribbean island of Aruba. Additionally, we studied fish assemblages on various coral reefs differing in proximity to seagrass Thalassia testudinum and mangrove Rhizophora mangle habitats at the scale of the whole island. In the seagrass and mangrove habitats, habitat configuration in relation to the reef was related to the composition of the fish assemblage, species richness, fish density and fish size. This was consistent with our expectations related to accessibility of these habitats from the reef, and habitat complexity. Most fish species that use seagrasses and mangroves as juvenile habitats were absent from or showed reduced densities on coral reefs located far $(>9 \mathrm{~km})$ from seagrass-mangrove habitats. At a smaller spatial scale, this effect was less clear. For some species, this lack of an effect at smaller spatial scales may be explained by local recruitment to the reef, whereas for other species (i.e. Haemulon sciurus, Lutjanus apodus, L. mahogoni and Scarus guacamaia) migration along the coast offers a more likely explanation. We suggest that the value of seagrass and mangrove habitats as a juvenile habitat should not be generalised a priori, since habitat configuration may interact with the degree of connectivity between seagrasses, mangroves and coral reefs.
\end{abstract}

KEY WORDS: Coral reef fishes $\cdot$ Habitat configuration $\cdot$ Connectivity $\cdot$ Juvenile $\cdot$ Dependence Seagrass beds · Mangroves

Resale or republication not permitted without written consent of the publisher

\section{INTRODUCTION}

Shallow back-reef habitats such as seagrass beds and mangroves are thought to be important nurseries for several Caribbean coral reef fish species. This concept is based on field studies, which showed that the highest juvenile densities of coral reef fish species were found in back-reef habitats, whereas the highest adult densities were observed on the coral reef (Parrish 1989, Nagelkerken et al. 2000, Eggleston et al. 2004).
However, ontogenetic migrations of fishes from these back-reef habitats towards the coral reef have not been proven directly. Therefore, it is debated whether back-reef habitats really contribute to the fish population on the coral reef, or only function as an additional habitat (Beck et al. 2001, Heck et al. 2003). Several studies have shown clear effects of the presence of seagrass beds or mangroves on fish assemblages on coral reefs, suggesting a high dependence of some species on these habitats, either at the scale of multiple islands 
(Nagelkerken et al. 2002, Halpern 2004) or of single islands (Serafy et al. 2003, Dorenbosch et al. 2004, Mumby et al. 2004). However, Chitaro et al. (2005) found substantial variation between sites in the abundance of juvenile fishes, indicating that not all seagrass beds and mangroves function equally as juvenile habitats. These results caution against the generalisation that all mangrove and seagrass habitats have a similar function as a juvenile fish habitat.

The nursery hypothesis is based on differences in the suitability of habitats for fishes at different life stages. Fish species exploit these differences in suitability by ontogenetic migrations between the habitats. Seagrass and mangrove habitats are likely to be attractive for juvenile fishes because they are characterised by high food availability and low predation pressure (Blaber 2000, Dahlgren \& Eggleston 2000, Beck et al. 2001). When fishes reach maturity, it is assumed that they migrate to the coral reef because this habitat is more suitable for adults, e.g. in terms of reproduction, food and shelter, resulting in low adult densities in seagrass and mangrove habitats. However, the impact of factors like food availability and predation pressure depends not only on the type of habitat (i.e. seagrass bed, mangrove, coral reef) per se, but is also likely to be influenced by the way the various habitat types are arranged within the coastal landscape, the so-called 'habitat configuration' (Garcia-Charton \& Perez-Ruzafa 1999, Beets et al. 2003, Serafy et al. 2003, Grober-Dunsmore et al. 2004, Pittman et al. 2004). In the Caribbean, seagrass beds and mangroves can be located directly adjacent to a coral reef, in bays with an open connection to a coral reef, or in semi-enclosed lagoons that are only connected to a coral reef by a narrow entrance channel. This spatial arrangement may determine the use of these seagrass-mangrove habitats by juvenile coral reef fish. Both recruitment into these habitats and ontogenetic migrations towards the reef may be easier in open systems than in semi-enclosed systems (Gratwicke \& Speight 2005). However, open systems are also more accessible for migrating predators, resulting in a higher predation pressure in these habitats than in habitats in semi-enclosed bays away from the coral reef (Bullard \& Hay 2002, Belmaker et al. 2005). Habitat configuration should therefore be taken into account when assessing the value and contribution of seagrass-mangrove habitats to the fish assemblage on the coral reef, and vice versa (Eggleston et al. 2004, Chitaro et al. 2005).

In the present study, the effect of habitat configuration on the use of seagrass beds, mangroves and coral reefs by juvenile and adult coral reef fishes was investigated at the scale of an entire island landscape. We hypothesised that the utilisation of the seagrass-man- grove habitats would be determined by the configuration of these habitats in the landscape in relation to the coral reef. Seagrass-mangrove habitats arranged in a semi-enclosed lagoon located away from the reef were expected to differ in fish species assemblage composition from habitats located in open bays or directly adjacent to a coral reef. We expected that more 'nursery species' such as those listed and defined by Nagelkerken et al. (2000) and Dorenbosch et al. (2004) would be present in the former habitats and more reef-associated species in the latter cases. Since predation pressure is likely to be influenced by the distance to the coral reef (Shulman 1985) and the structural complexity of a habitat (Nanani \& Nishihira 2001), we expected that juvenile fish densities would be lowest in seagrass-mangrove habitats which are easily accessible from the coral reef and which provide little shelter (i.e. seagrass beds adjacent to a coral reef). Fish size was expected to increase with increasing structural complexity of a habitat type (i.e. seagrass beds only provide shelter for smaller fishes whereas mangroves also provide shelter for larger fishes), and with increasing accessibility to the reef (resulting in higher density of predators feeding on juvenile fishes). Furthermore, densities of nursery species are expected to be higher on coral reefs near seagrass-mangrove habitats than on those situated further away. Finally, we expected the degree of similarity between fish assemblages of coral reef sites and seagrass-mangrove habitat sites to decline with increasing distance between the sites.

The island of Aruba (southern Caribbean Sea) features various seagrass-mangrove habitat types, which are arranged in an open bay (seagrass beds), in semienclosed lagoons (seagrass beds and mangroves) or directly adjacent to the reef (seagrass beds and mangroves). In short, there is a gradient from structurally simple and sheltered habitats (i.e. lagoon seagrass beds) to structurally complex and easily accessible habitats (i.e. mangroves adjacent to reefs). A further distinction can be made in coral reefs that are located adjacent to seagrass-mangrove habitats in an open bay or a semi-enclosed lagoon, and coral reefs that are isolated from any seagrass-mangrove habitats.

Based on our hypothesis that habitat configuration determines habitat utilisation, the island of Aruba offered a good opportunity to investigate the following: (1) Are habitat configuration (in relation to the coral reef) and habitat type (i.e. different structural complexity between seagrass beds and mangroves) related to the utilisation of seagrass beds and mangroves by juvenile coral reef fishes? (2) Are densities on coral reefs of fish species that use seagrass beds and mangroves as a juvenile habitat related to the proximity of seagrass beds and mangroves? 


\section{MATERIALS AND METHODS}

Study area and study design. We studied the fish assemblages of coral reefs and seagrass-mangrove habitat types on the Caribbean island of Aruba (Fig. 1). In total, 4 coral reef habitat types divided between 13 coral reef sites were surveyed along the entire coast of the island (Fig. 1, Table 1): (1) lagoon reefs (sheltered coral reefs located directly outside a semi-enclosed lagoon which harbours seagrass beds and mangroves, $n=7$ ), (2) patch reefs (sheltered patch reefs in front of an open sandy bay which harbours patches of seagrass beds, $n=2$ ), (3) exposed east reefs (exposed coral reefs at the eastern side of the island located far from seagrass-mangrove habitats [minimum distance to seagrass-mangrove habitats $9 \mathrm{~km}$ ], $\mathrm{n}=2$ ); and (4) isolated north reefs (isolated exposed reefs at the northern side of the island [distance to seagrass-mangrove $>10 \mathrm{~km}], \mathrm{n}=7$ ). The northern and eastern coasts of the island are its most exposed sides, lacking sheltered seagrass-mangrove habitats. Consequently, all surveyed seagrassmangrove habitats were situated on the sheltered western and southern sides of the island (Fig. 1, Table 2). These comprised (1) reef mangroves (mangroves directly adjacent to the lagoon reefs, $\mathrm{n}=2$ ); (2) lagoon mangroves $(n=2)$, (3) lagoon seagrass (seagrass beds, $\mathrm{n}=1$ ) (Habitats 2 and 3 are both located in a semienclosed lagoon $1.3 \mathrm{~km}$ distant from the coral reef), (4) reef seagrass (seagrass beds located in one of the entrances of this semi-enclosed lagoon but adjacent to the coral reef, $n=1$ ) and (5) open seagrass (seagrass beds situated in an open bay $1.6 \mathrm{~km}$ from the patch reefs, $\mathrm{n}=1$ ). Mangroves consisted of Rhizophora mangle only, and their inundated prop root system had an average width of $2 \mathrm{~m}$. All seagrass beds consisted of Thalassia testudinum with $100 \%$ bottom cover. The surveyed lagoon seagrass beds were located directly adjacent to lagoon mangroves. At the lagoon reefs and 1 exposed east reef (Baby Beach, Coral Reef No. 13, Fig. 1), a shallow reef flat, dropoff and reef slope could be distinguished. The other coral reefs consisted of low an-

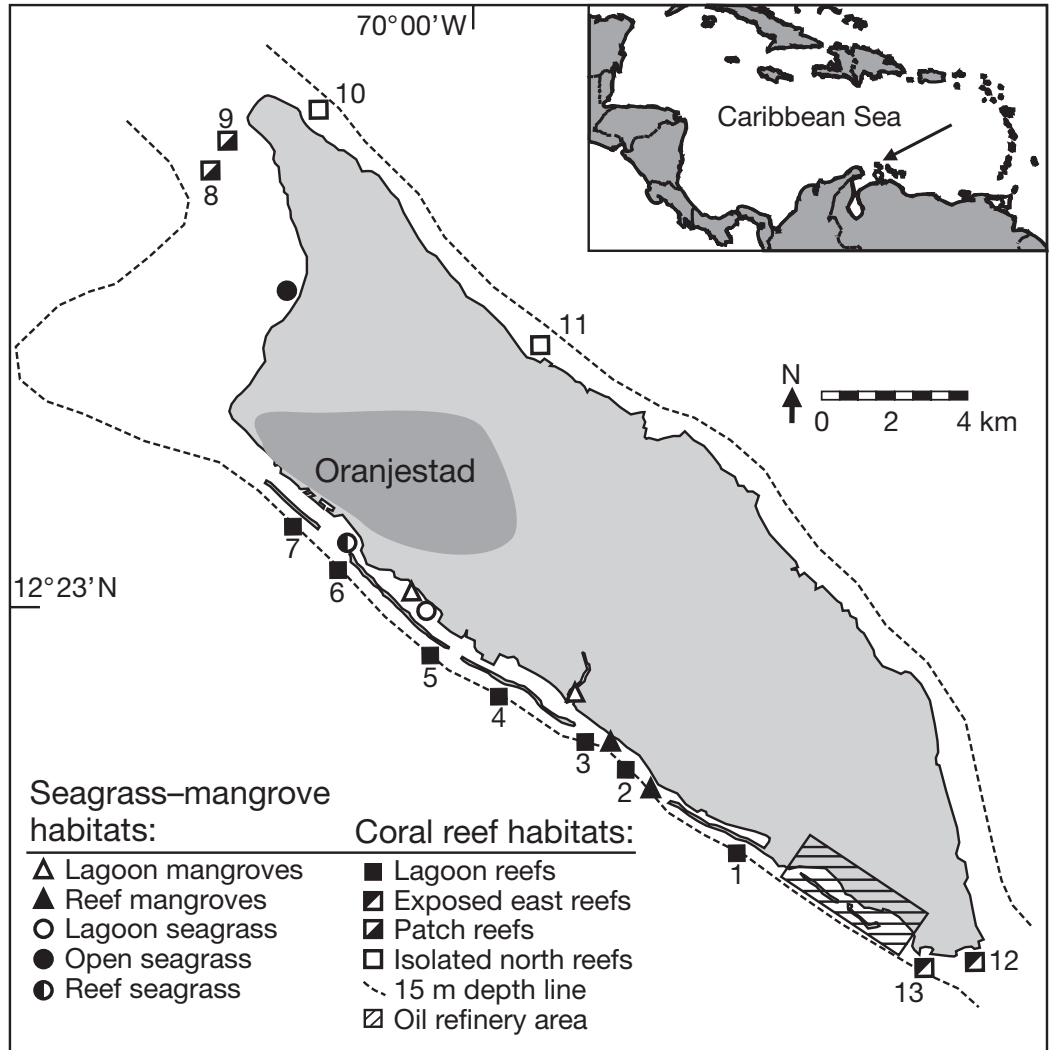

Fig. 1. Location of seagrass Thalassia testudinum, mangrove Rhizophora mangle and coral reef habitat types surveyed off the coast of the island of Aruba (numbers of coral reef sites correspond to those in Table 1)

Table 1. Habitat type and characteristics of surveyed quadrats of coral reef habitats (habitats numbered as in Fig. 1). n: no. of quadrats $(10 \times 10 \mathrm{~m})$ surveyed; area: total area surveyed

\begin{tabular}{|c|c|c|c|c|c|c|}
\hline Habitat (No.) & $\begin{array}{l}\text { Depth } \\
\text { (m) }\end{array}$ & $\begin{array}{c}\text { Coral c } \\
\text { soft }\end{array}$ & $\begin{array}{l}\text { over (\%) } \\
\text { hard }\end{array}$ & $\begin{array}{l}\text { Max. reef } \\
\text { height }(m)\end{array}$ & $\mathrm{n}$ & $\begin{array}{c}\text { Area } \\
\left(\mathrm{m}^{2}\right)\end{array}$ \\
\hline \multicolumn{6}{|l|}{ Lagoon reefs } & \multirow[t]{8}{*}{31200} \\
\hline Commandeursbaai (1) & $5,10,15^{\mathrm{a}}$ & 35.4 & 41.7 & 1.5 & 44 & \\
\hline Isla di Oro (2) & $5,10,15^{\mathrm{a}}$ & 19.6 & 44.7 & 1.7 & 46 & \\
\hline Mangel Halto (3) & $5,10,15^{\mathrm{a}}$ & 13.3 & 63.6 & 1.7 & 46 & \\
\hline Palm Island (4) & $5,10,15^{\mathrm{a}}$ & 12.2 & 56.7 & 1.8 & 44 & \\
\hline Barcadera (5) & $5,10,15^{\mathrm{a}}$ & 20.3 & 30.6 & 1.1 & 41 & \\
\hline Sonesta Island (6) & $5,10,15^{\mathrm{a}}$ & 6.7 & 28.5 & 1.0 & 47 & \\
\hline Harbour Reef (7) & $5,10,15^{\mathrm{a}}$ & 23.1 & 27.4 & 1.0 & 44 & \\
\hline \multicolumn{6}{|l|}{ Exposed east reefs } & \multirow[t]{3}{*}{6500} \\
\hline Cabez (12) & 11.0 & 16.4 & 46.8 & 1.1 & 20 & \\
\hline Baby Beach (13) & $5,10,15^{\mathrm{a}}$ & 2.6 & 50.1 & 1.7 & 45 & \\
\hline \multicolumn{6}{|l|}{ Patch reefs } & \multirow[t]{3}{*}{6400} \\
\hline Arashi, Antilla (8) & 7.7 & 2.7 & 4.5 & 0.5 & 42 & \\
\hline Debbie (9) & 17.3 & 0.6 & 58.9 & 1.1 & 22 & \\
\hline \multicolumn{5}{|l|}{ Isolated north reefs } & & \multirow[t]{3}{*}{4200} \\
\hline California Reef (10) & 9.7 & 31.7 & 21.5 & 0.6 & 18 & \\
\hline Wariruri (11) & 10.8 & 12.7 & 0.0 & 0.5 & 24 & \\
\hline
\end{tabular}


Table 2. Habitat type and characteristics of surveyed quadrats of seagrass Thalassia testudinum and mangrove Rhizophora mangle habitats. n: no. of quadrats surveyed; area: total area surveyed. Shoot density and height only available for seagrass

\begin{tabular}{|c|c|c|c|c|c|c|c|}
\hline Habitat & $\begin{array}{l}\text { Depth } \\
(\mathrm{m})\end{array}$ & $\begin{array}{c}\text { Shoot den } \\
\text { mean }\end{array}$ & $\begin{array}{l}\text { sity }\left(\mathrm{m}^{-2}\right) \\
\mathrm{SD}\end{array}$ & $\begin{array}{c}\text { Shoot hei } \\
\text { mean }\end{array}$ & $\begin{array}{l}\text { ght }(\mathrm{cm}) \\
\mathrm{SD}\end{array}$ & $\mathrm{n}$ & $\begin{array}{l}\text { Area } \\
\left(\mathrm{m}^{2}\right)\end{array}$ \\
\hline Lagoon mangroves & 1.3 & & & & & $53^{\mathrm{a}}$ & 530 \\
\hline Reef mangroves & 0.7 & & & & & $56^{\mathrm{a}}$ & 560 \\
\hline Lagoon seagrass & 1.4 & 57.4 & 16.8 & 28.0 & 7.5 & $81^{\mathrm{b}}$ & 2025 \\
\hline Open seagrass & 1.0 & 93.4 & 15.0 & 29.0 & 4.1 & $79^{\mathrm{b}}$ & 1975 \\
\hline Reef seagrass & 2.1 & 59.2 & 8.8 & 30.4 & 5.4 & $41^{\mathrm{b}}$ & 1025 \\
\hline \multicolumn{8}{|c|}{${ }^{\mathrm{a}}$ Quadrat size $=5 \times 2 \mathrm{~m}$} \\
\hline
\end{tabular}

gle reef flats (Table 1). Although there is also a bay on the SE part of the island, there are no seagrass-mangrove habitats here, since the bay is completely occupied by an oil refinery (Fig. 1).

The entire reef fish community was surveyed with the exception of cryptic species (Atherinidae, Clinidae and Gobiidae). Fish assemblages were studied by 3 independent observers by means of visual census surveys using SCUBA and a stationary point-count method described in Dorenbosch et al. (2004). This method was also used to survey fish assemblages in the seagrass-mangrove habitats, but here snorkelling gear was used instead of SCUBA because of the shallowness of these habitats. Fishes were counted in size classes of $2.5 \mathrm{~cm}$ (total length). Estimation of size classes was first thoroughly practiced simultaneously by the 3 observers. Since underwater visibility was different in the coral reef $(>12 \mathrm{~m})$ and seagrassmangrove (5 to $12 \mathrm{~m}$ ) habitats, quadrat size was $10 \times$ $10 \mathrm{~m}$ on the coral reef, and $5 \times 5 \mathrm{~m}$ in the seagrass beds. The shape and width of the mangroves only allowed transect sizes of $5 \times 2 \mathrm{~m}$ in the mangroves. However, these transects covered the entire mangrove habitat accessible to fishes, and allowed us to sample the complete fish assemblage in this habitat using visual census. Fringing coral reefs were divided into 3 depth zones: reef flat (mean water depth $5 \mathrm{~m}$ ), drop-off $(10 \mathrm{~m})$ and slope $(15 \mathrm{~m})$. In each zone, replicate quadrats were surveyed (Table 1). For each coral reef quadrat we sampled, we recorded water depth $(\mathrm{m})$, hard coral cover (\%), soft coral cover (\%) and maximum height of corals above the substratum $(\mathrm{m})$. For each seagrass site, mean shoot density was measured in $25 \times 25 \mathrm{~cm}$ quadrats randomly placed in seagrass beds where fish quadrats were surveyed ( $\mathrm{n}=40$ for lagoon seagrass, $\mathrm{n}=20$ for reef seagrass, $\mathrm{n}=20$ for open seagrass). At the same locations in the seagrass beds, shoot heights of randomly selected seagrass plants were measured $(\mathrm{cm})$ and averaged for each seagrass site
( $\mathrm{n}=273$ for lagoon seagrass, $\mathrm{n}=60$ for reef seagrass, $n=60$ for open seagrass). Characteristics and the number of quadrats surveyed per habitat type are listed in Table 2. All data were collected during the daytime between October and December 2004.

Although seagrass and mangrove sites were not homogeneously distributed along the SW shore of the island, environmental variables (such as salinity, water currents, disturbance and pollution), are very similar at these sites and their influence on differences in the structure of fish assemblages are thought to be negligible. Furthermore, all seagrass-mangrove sites were distributed in a relatively small geographic scale (approx. $16 \mathrm{~km}$ width), all located on the leeward coast of the island, and subject to a prevailing, slow, westward, surface ocean current (Anonymous 1953). Additionally, there are no freshwater rivers discharging into the waters off the coast of Aruba, the tidal range is only $30 \mathrm{~cm}$ (de Haan \& Zaneveld 1959), and anthropogenic disturbance is similar along the gradient.

Data analysis. Since this study focuses on the connectivity between fish assemblages of seagrass, mangrove and coral reef habitats, only fish species that were observed in both seagrass-mangrove habitats and coral reef habitats were included in further analyses. Fishes were considered to be juveniles when they were smaller than one third of the maximum species length (Nagelkerken \& van der Velde 2002, Dorenbosch et al. 2004, 2005). Maximum lengths of species were obtained from Froese \& Pauly (2005; available at: http\\www.fishbase.org). Species with a maximum length $>90 \mathrm{~cm}$ were recorded as juveniles when observed individuals were $<30 \mathrm{~cm}$. For each habitat type, mean total juvenile and adult densities were determined based on all surveyed quadrats, pooling all species. Subsequently, a juvenile:adult ratio was calculated for each quadrat, using total juvenile fish density and total adult fish density of the quadrat. Based on this ratio per quadrat, mean juvenile:adult ratios were calculated for each habitat type. Besides juvenile and adult fish densities in each habitat type, we also determined total species richness by pooling juveniles and adults. For the 4 coral reef habitats, each surveyed quadrat was used as a replicate. Since the quadrat size differed between seagrass-mangrove habitats, 4 seagrass bed quadrats and 10 mangrove transects were pooled to obtain standardised quadrat sizes of $100 \mathrm{~m}^{2}$. Although the pooling of several smaller quadrats as compared to 1 large quadrat may affect the exact value of species richness, it provides a good approximation of 
this variable (Dorenbosch et al. 2005). These standardised quadrats were used to calculate the mean total species richness of each seagrass-mangrove habitat type. Based on field surveys in a shallow water bay on the Caribbean island of Curaçao, Nagelkerken et al. (2000) defined 17 nursery species (i.e. coral reef species that are thought to be highly associated with seagrass beds and mangroves during their juvenile life phase: see Table 4, this study). Total juvenile and adult densities, species richness and juvenile:adult ratios of these 17 nursery species were also calculated in all habitat types in the present study. To assess the utilisation of seagrass and mangrove habitat types in relation to fish size, mean fish density in each habitat type was calculated in $5 \mathrm{~cm}$ size classes, pooling all species per habitat type.

To investigate the relationship between fish assemblages of various coral reef and seagrass-mangrove habitat types, a cluster analysis was performed using BioDiversity Pro (McAleece 1997). Cluster analysis was performed on log-transformed densities of all species observed on both the coral reef and seagrassmangrove habitats (pooling juveniles and adults), based on the group average linkage method and the Euclidean distance index (Jongman et al. 1995).

To investigate the relationship between the similarity in fish assemblages of coral reef sites and seagrassmangrove sites and their geographic distances, both Euclidean distances and geographic distances between sites were calculated. Euclidean distances were based on log-transformed mean juvenile and adult fish densities of these species using BioDiversity Pro. Geographical distances between the various coral reef sites and seagrass-mangrove habitat types were measured on a map (1:50 000) according to the shortest possible distance fishes had to swim between sites. The calculated Euclidean distances (set as regressor) were used for linear regressions with the shortest geographical distance between coral reef sites and the various seagrassmangrove habitat types (dependent variable). Linearity and residuals versus predicted values were checked for violation of linear regression assumptions.

At species level, we analysed the relationship between each fish species density (pooling all juveniles and adults at each coral reef site) and the distance to seagrass-mangrove habitats by means of linear regression. This was done only for those species for which $>20$ juvenile individuals had been observed in seagrass-mangrove habitats (these species represented $98.5 \%$ of all juvenile individuals counted in seagrass-mangrove habitats: further referred to as 'common seagrass-mangrove species'; see 'Results'). Two regression analyses were performed, one determining the relationship between fish species densities at coral reef sites and the shortest distance to one of the entrances of the lagoon harbouring mangroves and seagrass beds, the other determining the relationship with the shortest distance to the nearest seagrass-mangrove habitat. Fish species density was used as the dependent variable, distance as the regressor. Linearity and residuals versus predicted values were checked for violation of linear regression assumptions.

To compare fish assemblages between seagrass, mangrove and coral reef habitats, fish counts of quadrats collected in seagrass beds $\left(25 \mathrm{~m}^{2}\right.$ quadrat size) and transects in mangroves $\left(10 \mathrm{~m}^{2}\right.$ transect size) were transformed to fish counts of standardised quadrats (100 $\mathrm{m}^{2}$ quadrat size). Because these differences in methodology of sampling between habitats may confound with ordinary ANOVA models, mean juvenile and adult fish density and total species richness between seagrass, mangrove and coral reef habitats were compared using linear mixed models, fitted with the MIXED procedure (SAS Institute 1993). Compound symmetry was set as covariance structure.

When comparing fish densities or species richness between habitats sampled using similar methodology (within seagrass beds, mangroves or coral reefs), this problem of different methodology does not occur. Because total fish densities were based on count data and their distribution could be best described by a Poisson distribution, statistical differences between total densities of fish in $5 \mathrm{~cm}$ size classes in the seagrass-mangrove habitats were therefore analysed using generalised linear models based on Poisson distributions (similar to a design used by Mazerolle et al. 2001), fitted with the GENMOD procedure (SAS Institute 1993). Since most models showed a moderate overdispersion, we corrected the model for overdispersion by introducing a dispersion parameter into the relationship between the variance and the mean (according to Pedan 2006).

Mean juvenile:adult ratio per habitat type was calculated separately for nursery species (see above) and the remaining other species (non-nursery species). Because the ratio data violated parametric test assumptions (even after transformation), statistical differences between mean juvenile:adult ratios were tested using a non-parametric Kruskal-Wallis test.

The effect of habitat configuration on the fish assemblage and individual species on the coral reef was studied by distinguishing 4 reef types that differed in their proximity to seagrass-mangrove habitats (lagoon reefs, exposed east reefs, sheltered patch reefs and isolated north reefs). For common seagrass-mangrove species (as defined above), mean total fish densities were compared between these 4 reef types, using the above described generalised linear models (methodology for determination of fish assemblages on coral reefs 
was similar for all coral reef sites). Covariables, viz. quadrat depth, hard coral cover and/or soft coral cover were added to the model if additional multiple linear regressions showed a significant relationship between these reef complexity variables and fish density. Multicolinearity between reef complexity variables was tested using non-parametric correlations. Coral height was correlated with hard coral cover (correlation $=0.54$; $\mathrm{p}<0.001$ ) and was excluded from further analysis.

The effect of the configuration of seagrass-mangrove habitats on total species richness of all nursery species and of all common seagrass-mangrove species (based on untransformed data) was tested using a general linear model (based on ANOVA). Habitat types were set as a fixed factor. The covariables quadrat depth, hard coral cover and/or soft coral were added to this model if linear relationships with species richness were significant.

Differences in least squares means were used for post-hoc comparisons in linear mixed models and generalised linear models. Significance of all relationships was evaluated with the Wald $\chi^{2}$ statistic. Post-hoc comparisons of total species richness of all nursery species between the 4 coral reef habitat types (general linear model) and the Kruskal-Wallis test (juvenile:adult ratios) were done using a Games-Howell test; post-hoc comparisons of total species richness of common seagrass-mangrove species between the 4 coral reef habitat types were done using a Hochberg's GT2 test.

For each generalised linear model, the fit of the model was visually evaluated by comparing the observed and estimated cumulative distribution functions (Poisson distribution versus negative binominal distribution [Pedan 2006]), and residuals were checked for normality. For each general linear model, parametric assumptions were checked. General linear models, the KruskalWallis test, and the Games-Howell/Hochberg's GT2 post-hoc comparisons were performed using SPSS 14.0.

According to the hypothesis outlined in the 'Introduction', low densities or absence of nursery species was expected on coral reefs located far away from seagrassmangrove habitats. In contrast to the nursery species, their non-nursery reef congeners are not likely to show this pattern. The proportion of nursery species in relation to their reef congeners is therefore expected to be high on coral reefs close to seagrass-mangrove habitats (lagoon reefs) and low on coral reefs farthest away from these habitats (isolated north reefs). To test this possibility, the mean proportion of nursery species in relation to their reef congeners was calculated for each reef type (quadrats were used as replicates) as follows: proportion nursery species $_{\text {quadrat }}=$ (total density nursery

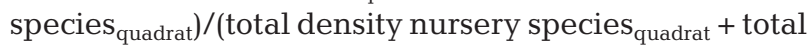
density reef congeners quadrat $_{\text {). Statistical differences }}$ between mean proportions were tested using a nonparametric Kruskal-Wallis test (parametric assumptions were violated, even after transformation), followed by a Games-Howell post-hoc comparison.

\section{RESULTS}

A total of 61 fish species were observed in both the coral reef and seagrass-mangrove habitats. These species were included in further analyses of fish densities and species richness. For 28 of these species, more than 20 juveniles were counted in seagrass-mangrove habitats. These 28 species (called 'common seagrassmangrove species'; see Table 4) represented 98.5\% of all juvenile individuals counted in the seagrassmangrove habitats.

Fish assemblages on seagrass-mangrove sites were affected by their location relative to the coral reef. Adult fish densities in mangroves were significantly higher in reef mangroves than in lagoon mangroves (Fig. 2; linear mixed model, $F_{\mathrm{df}=8}=85.82, \mathrm{p}<0.001$ ). This was predominantly caused by higher densities of non-nursery species in reef mangroves, since densities of nursery species were similar in the 2 habitats. This high adult fish density in reef mangroves was reflected by significantly larger fishes in reef mangroves compared to lagoon mangroves (see Fig. 5a; generalised linear model, Table 3). Although total juvenile densities were similar in both reef and lagoon mangroves, there was a trend comparable to that mentioned above for the adults, and reef mangroves showed higher juvenile densities of non-nursery species than lagoon mangroves (Fig. 2). This pattern is also illustrated

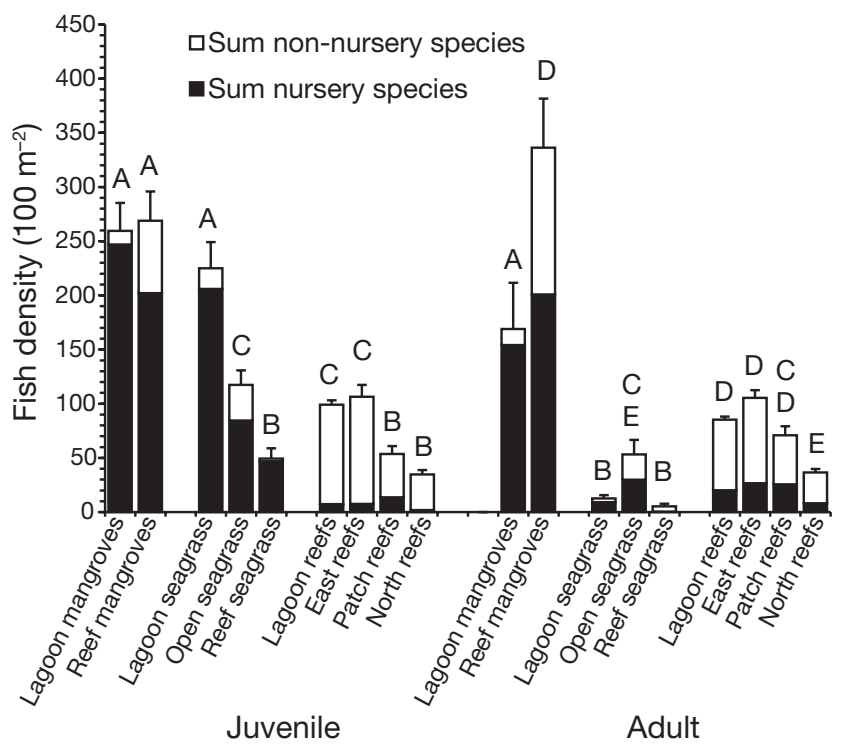

Fig. 2. Mean (+SE) total juvenile and adult fish density as a function of habitat type. Different letters indicate significant differences $(p<0.05)$; nursery species defined according to Nagelkerken et al. (2000), (see Table 4) 
Table 3. Statistical results of generalised linear models and post-hoc comparisons ( $p$-values) of size-class distribution of fishes in (a) seagrass (Thalassia testudinum) beds and (b) mangroves (Rhizophora mangle) (all species pooled, see also

Fig. 3). ns: not significant; np: test could not be performed

\begin{tabular}{|lcccr|}
\hline $\begin{array}{l}\text { (a) Seagrass beds } \\
\text { Size class } \\
\text { (cm) }\end{array}$ & $\begin{array}{c}\text { Significancy } \\
\text { of the model }\end{array}$ & $\begin{array}{c}\text { Lagoon/ } \\
\text { open }\end{array}$ & $\begin{array}{c}\text { Lagoon/ } \\
\text { reef }\end{array}$ & $\begin{array}{c}\text { Open/ } \\
\text { reef }\end{array}$ \\
\hline $0-5$ & $<0.001$ & $<0.001$ & $\mathrm{~ns}$ & 0.025 \\
$5-10$ & $<0.001$ & 0.001 & $<0.001$ & $<0.001$ \\
$10-15$ & $<0.001$ & 0.001 & $\mathrm{~ns}$ & 0.000 \\
$15-20$ & 0.001 & $\mathrm{~ns}$ & 0.024 & 0.008 \\
$20-25$ & $<0.001$ & $\mathrm{~ns}$ & $\mathrm{~ns}$ & 0.009 \\
$25-30$ & $<0.001$ & 0.005 & $\mathrm{~ns}$ & 0.008 \\
$>30$ & $\mathrm{np}$ & & & \\
(b) Mangroves & & & & \\
Size class & $\begin{array}{c}\text { Significancy } \\
\text { (cm) }\end{array}$ & Reef/ & & \\
\hline $0-5$ & the model & lagoon & & \\
$5-10$ & $\mathrm{~ns}$ & $\mathrm{~ns}$ & & \\
$10-15$ & $<0.001$ & $\mathrm{~ns}$ & & \\
$15-20$ & $\mathrm{~ns}$ & $\mathrm{~ns}$ & & \\
$20-25$ & $<0.001$ & $<0.001$ & & \\
$25-30$ & $<0.001$ & 0.001 & & \\
$>30$ & $\mathrm{~ns}$ & $\mathrm{~ns}$ & & \\
& $\mathrm{np}$ & & \\
\hline
\end{tabular}

when the juvenile:adult ratios are compared between nursery and non-nursery species in reef and lagoon mangroves (Fig. 3). Mean species richness showed a pattern similar to that of adult density, and was significantly higher in reef mangroves as a result of high numbers of non-nursery species (Fig. 4 ; linear mixed model, $\left.F_{\mathrm{df}=8}=79.92 ; \mathrm{p}<0.001\right)$.

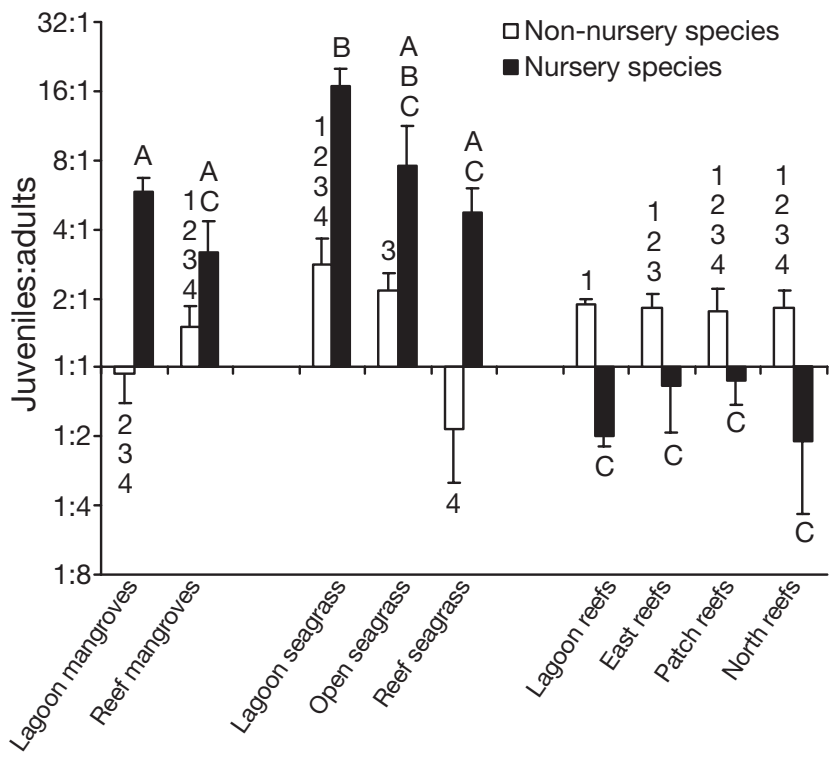

Fig. 3. Mean (+SE) juvenile:adult fish density ratio as a function of habitat type. Different numbers and letters indicate significant differences $(p<0.05)$
Similar to mangroves, the distance between the seagrass beds and the coral reef had a clear effect on the fish assemblage in seagrass beds. Sheltered lagoon seagrass beds located away from the reef showed significantly highest juvenile densities of the 3 seagrass habitat types, whereas reef seagrass beds showed significantly lowest juvenile densities (Fig. 2; linear mixed model, $F_{\mathrm{df}=8}=$ $35.37, \mathrm{p}<0.001)$. These differences were mainly caused by nursery species. This pattern was also clearly illustrated by the juvenile:adult ratios of nursery and nonnursery species (Fig. 3; Kruskal-Wallis test, nursery species:, $\chi_{\mathrm{df}=8}^{2}=222.68, \mathrm{p}<0.001$, non-nursery species: $\left.\chi_{\mathrm{df}=8}^{2}=56.80 ; \mathrm{p}<0.001\right)$. juvenile:adult ratios were high in all 3 seagrass habitats for nursery species, but the ratio was highest in lagoon seagrass beds. Adult densities were low in all 3 seagrass habitats, with open seagrass beds showing the highest adult density, predominantly caused by nursery species (Fig. 2). Reef seagrass beds showed a clearly reduced juvenile:adult ratio for non-nursery species (Fig. 3), resulting from high densities of non-nursery adults (Fig. 2). Total species richness showed a pattern similar to that of adult fish densities (Fig. 4). With respect to fish size, the lagoon seagrass beds harboured the highest density of smallest fishes (Fig. 5b, Table 3), as was the case for lagoon mangroves.

Not only did a larger distance from the coral reef affect fish assemblages in seagrass beds and mangroves, but there also appeared to be an influence of the configuration of seagrass-mangrove habitats with respect to the reef on the fish assemblage on the coral reef. The coral reef sites isolated from lagoon habitats (i.e. patch reefs and isolated north reefs) showed significantly lower total juvenile fish densities and species richness (Figs. $2 \& 4$,

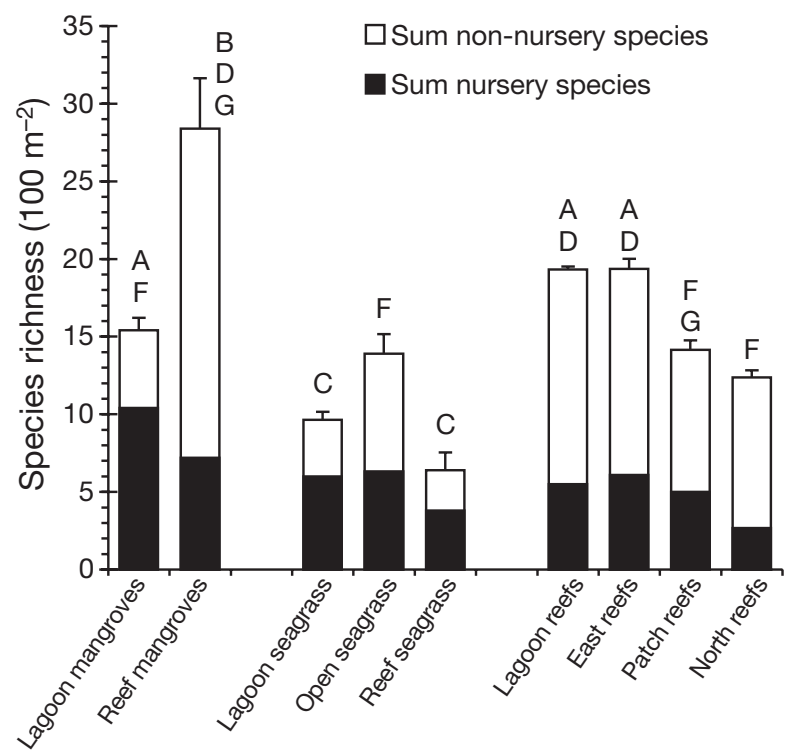

Fig. 4. Mean (+SE) total fish species richness as a function of habitat type. Different letters indicate significant differences $(\mathrm{p}<0.05)$ 


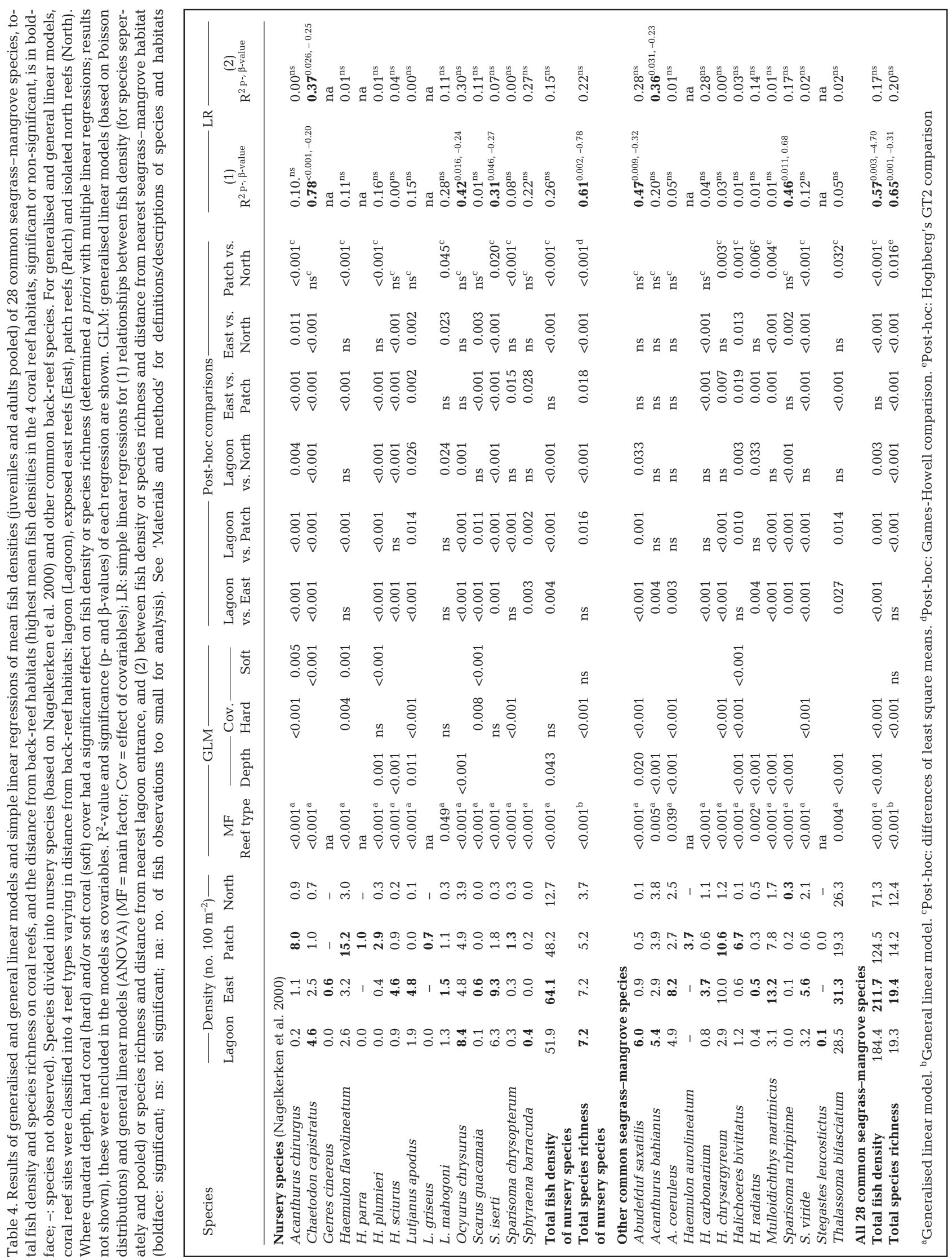



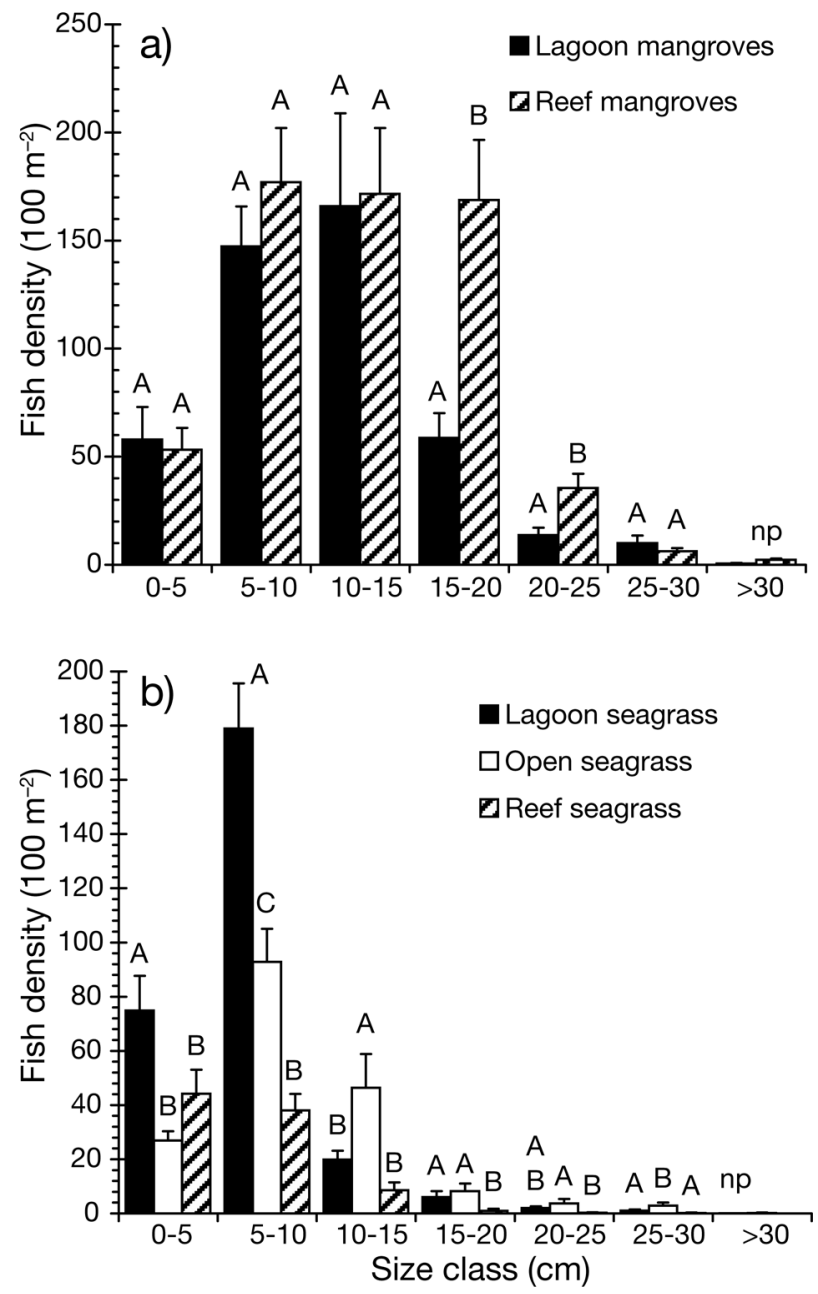

Fig. 5. Mean (+ SE) fish density in $5 \mathrm{~cm}$ size classes (all species pooled) for (a) mangrove Rhizophora mangle habitats and (b) seagrass Thalassia testudinum habitats. Different letters indicate significant differences within 1 size class. np: statistical test could not be performed (number of observations was too low)

linear mixed models), and total fish density and species richness (pooling all juveniles and adults, general linear models, Table 4). Total adult fish density (Fig. 2, linear mixed model) was only significantly lower on isolated north reefs. For all reef types, total juvenile densities of nursery species were low, with the lowest densities observed on reefs located farthest away from lagoon habitats (i.e. isolated north reefs).

In accordance with the above mentioned results, cluster analysis showed that fish assemblages in each habitat could be arranged into clusters according to habitat type (i.e. mangroves, seagrass beds and coral reefs) and according to distance to the coral reef (i.e. reef mangroves versus lagoon mangroves, and open and reef seagrass beds versus lagoon seagrass beds) or to configuration of seagrass-mangrove habitats with respect to the reef (i.e. lagoon reefs and exposed east reefs versus isolated north reefs and patch reefs, Fig. 6).

With respect to their reef congeners, the mean proportion of nursery species was significantly reduced on the most isolated coral reef habitat (isolated north reefs), whereas the highest proportion was observed on patch reefs (Fig. 7; Kruskal-Wallis test, $\chi^{2}$ df $=3=$ 44.04, $\mathrm{p}<0.001$ ).

Generalised linear models of total fish densities on the coral reef were significant for 23 of the 28 common seagrass-mangrove fish species (Table 4 ). The covari-

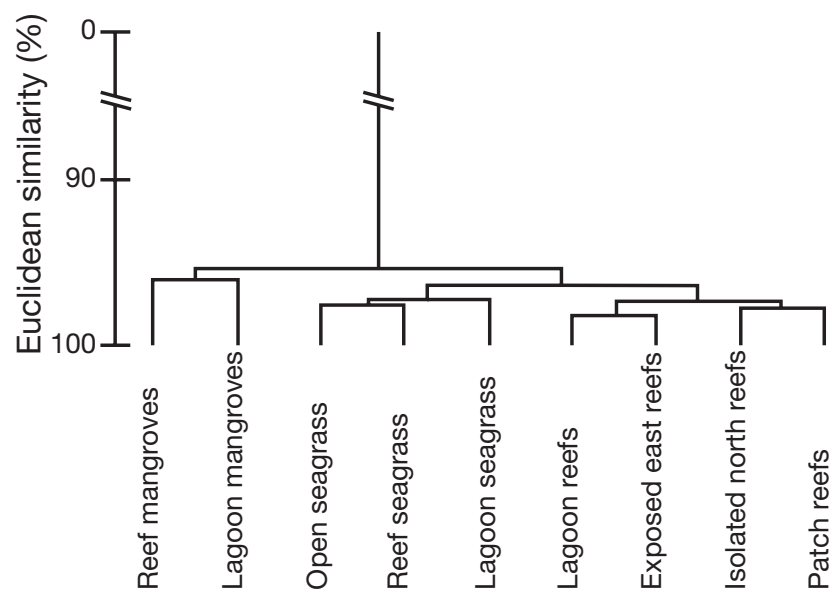

Fig. 6. Euclidean cluster analysis of all fish species observed on the various seagrass-mangrove (Thalassia testudinumRhizophora mangle) habitat and coral reef habitat types. Cluster analysis performed on log-transformed species densities was based on group average linkage method

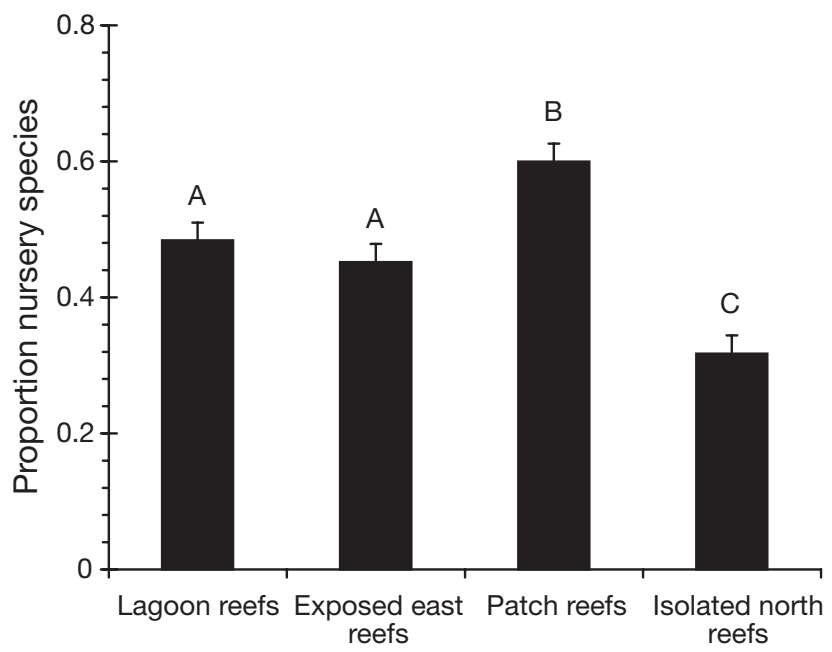

Fig. 7. Mean $(+\mathrm{SE})$ proportion of nursery species in relation to their non-nursery reef congeners on the 4 coral reef habitat types (quadrats were used as replicates). Different letters indicate significant differences $(\mathrm{p}<0.05)$ 
ables quadrat depth, and hard coral and soft coral cover, had significant effects on various species densities but no consistent pattern could be distinguished (Table 4). The influence of configuration of seagrassmangrove habitats with respect to the reef can also be illustrated at the level of these 28 common seagrass-mangrove species. Compared with lagoon reefs, the isolated north reefs showed significantly lower densities of 6 nursery species (Chaetodon capistratus, Haemulon sciurus, Lutjanus apodus, L. mahogani, Ocyurus chrysurus and Scarus iserti), whereas 2 nursery species (Scarus guacamaia and Sphyraena barracuda) showed densities close to zero on isolated north reefs $\left(<0.03\right.$ individuals $100 \mathrm{~m}^{-2}$, Table 4$)$. Three nursery species (Gerres cinereus, Haemulon parra and Lutjanus griseus) were observed on lagoon reefs but were absent from isolated north reefs (Table 4). Of the non-nursery common seagrass-mangrove fish species, 2 species (Abudefduf saxatilis and Halichoeres bivittatus) showed significantly lower densities on isolated north reefs than on lagoon reefs. Stegastes leucostictus was observed on lagoon reefs but was absent from isolated north reefs, while Haemulon aurolineatum was exclusively observed on patch reefs (Table 4). In total, 16 nursery species showed reduced densities or absence on isolated north reefs compared to the other reef types.

At a smaller scale, such a general pattern was not visible (i.e. excluding north reefs). When fish densities of common seagrass-mangrove species were compared between lagoon reefs, exposed east reefs and patch reefs, only 3 species (i.e. 2 nursery species: Chaetodon capistratus and Ocyurus chrysurus, and 1 other common species: Abudefduf saxatilis) showed significantly higher densities on lagoon reefs than in the other 2 reef habitats (Table 4).

Multiple linear regressions between the total density of each common seagrass-mangrove fish species on the coral reef sites and the distance to the nearest seagrass-mangrove habitat type did not show a clear pattern (Table 4). Only Acanthurus bahianus and Chaetodon capistratus showed a significant negative relationship between fish density and distance. In contrast, a significant negative relationship was observed between the total density of all species or total species richness and the distance to the nearest lagoon entrance (Table 4). At species level, a significant negative relationship was observed between distance to the nearest lagoon entrance and the density of Abudefduf saxatilis, C. capistratus, Ocyurus chrysurus and Scarus iserti (Table 4). Sparisoma rubripinne showed a significant positive relationship between fish density and this distance. Linear regressions of the degree of similarity between fish assemblages of seagrass-mangrove habitats and coral reef sites, with the shortest distance to each seagrass or mangrove habitat type were only significant for lagoon mangroves $\left(R^{2}=0.37\right.$, $\beta=-0.014, p=0.028)$.

\section{DISCUSSION}

\section{Configuration of seagrass-mangrove habitats}

It was hypothesised that the configuration of seagrass-mangrove habitats in relation to the coral reef would have a clear influence on the fish assemblages that used these habitats. The observations of the present study are consistent with this hypothesis. Firstly, reef mangroves were characterised by high species richness and by high adult densities, resulting in a low juvenile:adult ratio. Secondly, in contrast to this, open seagrass and reef seagrass beds were characterised by lower species richness and by low adult density. Compared to reef mangroves, both seagrass habitats have a lower structural complexity but are, like reef mangroves, easily accessible from the coral reef. Thirdly, where both habitat types were located away from the coral reef within the semi-enclosed lagoon (lagoon mangroves and lagoon seagrass), they were characterised by lower species richness but a high juvenile density. Lagoon mangroves showed a higher adult density than lagoon seagrass and are, like reef mangroves, characterised by a higher structural complexity than lagoon seagrass.

These observations may be explained by a combination of ecological processes, viz. short distance migration, ontogenetic migration, and predation on fishes with the ensuing importance of the shelter possibilities within a habitat. Adult reef-associated species (i.e. non-nursery species) are likely to migrate short distances away from the reef towards adjacent habitats (Tulevech \& Recksiek 1994, Kaunda-Arara \& Rose 2004). This short distance migration away from the reef may increase densities of non-nursery species in habitats close to the reef. Fishes are known to seek shelter in shaded habitats or in habitats with a high structural complexity (Laegdsgaard \& Johnson 2001, Cocheret de la Morinière et al. 2004, Eggleston et al. 2004, Verweij et al. 2006). Compared with open seagrass or reef seagrass beds, reef mangroves are shaded and are characterised by a high structural complexity which also provides shelter for larger (adult) fishes. Short distance migration of adult reef-associated species is therefore likely to influence fish assemblages in reef mangroves rather than in open seagrass or reef seagrass beds.

In addition to short distance migration, fish assemblages in reef mangroves may also be influenced by ontogenetic migration of species that use lagoon habi- 
tats as a juvenile habitat. Reef mangroves are located close to the entrance of the lagoon between the lagoon and the coral reefs and may therefore function as a stepwise habitat for adult and subadult fishes that have recently left habitats located further within the lagoon (Cocheret de la Morinière et al. 2002, Lecchini \& Galzin 2005).

The ecological importance of the structural complexity and configuration of the seagrass-mangrove habitats in relation to the coral reef is further supported by mean fish size in seagrass beds and mangroves. The most structurally complex habitat types, i.e. both mangrove habitat types, had higher densities of larger fishes than the less structurally complex seagrass habitats. The complex structure of mangroves is known to provide efficient shelter against predation (Laegdsgaard \& Johnson 2001). Seagrass beds may provide sufficient shelter for small juvenile fishes but, as these reach larger size, they may become too large for the shelter opportunities offered by seagrass beds and are forced to migrate towards habitats that provide better shelter, such as mangroves (Beets 1997, Nagelkerken et al. 2000, Nanami \& Nishihira 2001). This may explain the finding that fishes in lagoon mangroves were larger than those in the nearby lagoon seagrass beds.

Within the seagrass habitat types, lagoon seagrass beds predominantly harboured high densities of the 2 smallest size classes of fishes, with much lower densities of larger size classes. These low densities of larger size classes may be be due to ontogenetic migration to other habitats, such as the nearby lagoon or reef mangroves or the coral reef. A similar pattern was observed for reef seagrass beds, although the densities of most size classes were significantly lower than on lagoon seagrass beds. Predation pressure on the reef seagrass beds is likely to be higher than on open and especially lagoon seagrass beds because of the former's proximity to the reef (Shulman 1985). This may explain the low densities of most size classes in reef seagrass beds compared with the other seagrass beds. Predation pressure on fishes of the smallest 2 size classes in reef seagrass beds may be lower because the structural complexity of the seagrass beds may provide sufficient shelter opportunities for these small fishes (Hyndes et al. 2003). As a result of low structural complexity and possibly high predation pressure in reef seagrass beds, fishes that migrate from lagoon habitats towards the reef are not likely to use these seagrass beds as a permanent or temporary life-stage habitat. In contrast to reef and lagoon seagrass beds, open seagrass beds had higher densities of larger fishes (10 to $15 \mathrm{~cm}$ ). Fishes may spend a longer part of their life stage in open seagrass beds, possibly because there are no immediately adjacent habitats that provide more shelter.

\section{Configuration of coral reef habitats}

Based on the assumptions of the nursery hypothesis (see 'Introduction'), we hypothesised that fish densities on coral reefs isolated from seagrass-mangrove habitats would be characterised by low densities or the absence of coral reef species that depend on these habitats during their juvenile life phase. Coral reefs that were most isolated from seagrass-mangrove habitats (i.e. isolated north reefs) showed reduced densities or complete absence of 16 common seagrassmangrove fish species, consistent with the hypothesis that the presence and absence of seagrass-mangrove habitats at a large scale, viz. that of an entire island, is likely to influence the density of coral reef fish species on the coral reef (Nagelkerken et al. 2002, Halpern 2004). These results are most obvious for Ocyurus chrysurus and Chaetodon capistratus, and possibly explain their distribution on the coral reefs around the island of Aruba, showing highest densities on reefs in front of lagoons with seagrass-mangrove habitats and also a negative linear relationship with distance from these lagoons. A comparable influence of the proximity of seagrass-mangrove habitats on the density of $O$. chrysurus on coral reefs has also been shown on another Caribbean island (Dorenbosch et al. 2004).

Our hypothesis is also consistent with the observation of a reduced proportion of nursery species in relation to their non-nursery reef congeners on isolated north reefs. Although there may also be an unknown spatial effect influencing densities of all fish species on isolated north reefs, there is clearly an effect that has a specific influence on nursery species rather than on their non-nursery reef congeners. This suggests that the absence of shallow lagoons containing seagrass beds and mangroves is a more likely explanation for the reduced proportion of nursery species on isolated north reefs. Due to their congeneric nature, fish species can be assumed to be similar with respect to many life history traits, which makes it likely that the effect of factors other than the presence of seagrass beds and mangroves would have similar effects on both nursery species and their non-nursery reef congeners.

Some nursery species showed a deviation from these generally observed patterns. Whereas juvenile Scarus coeruleus and Lutjanus analis were associated with seagrass-mangrove habitats in previous studies (Nagelkerken et al. 2002, Dorenbosch et al. 2004), this pattern could not be demonstrated on Aruba. $S$. coeruleus was frequently observed on coral reefs on Aruba (mean \pm SD total density $0.28 \pm 1.13$ individuals $100 \mathrm{~m}^{-2}$ ), but juveniles rarely used seagrass-mangrove habitats, and it cannot be considered here as a species with a high dependence on seagrass beds and man- 
groves. L. analis was only observed in very low densities, suggesting that the presence of seagrass beds and mangroves is not the only factor determining densities of this species.

At a smaller scale (i.e. along the gradient lagoon reefs - patch reefs - exposed east reefs), the suggested effect of the proximity of seagrass-mangrove habitats was no longer evident for most species. Although 4 species occurred in significantly higher densities on lagoon reefs than on the other 2 reefs (Abudefduf saxatilis, Chaetodon capistratus, Ocyurus chrysurus and Sphyraena barracuda), all other common seagrassmangrove species showed different patterns. Likewise, most linear relationships between the fish density on coral reefs and the distance to seagrassmangrove habitats were not significant, and neither were linear relationships between the degree of similarity of the fish assemblage on the coral reef to the fish assemblage of seagrass-mangrove habitat types and the geographic distance between these habitats. The high densities of common seagrass-mangrove species on reefs that were not located directly adjacent to seagrass-mangrove habitats may have resulted from 2 processes: (1) local recruitment on coral reefs and/or (2), considering the small size of Aruba, long-distance migrations of adults and/or subadults of these species from seagrass-mangrove habitats along the entire SW coast of the island.

For 3 of the 5 species for which a dependence on seagrass-mangrove habitats had been suggested on the neighbouring island of Curaçao (Dorenbosch et al. 2004) and which were also recorded here in seagrass-mangrove habitats (Haemulon sciurus, Lutjanus apodus and $L$. mahogoni), highest densities were not found on lagoon reefs. However, since juvenile densities (mean no. $\pm \mathrm{SD} 100 \mathrm{~m}^{-2}$ ) on the coral reef were almost zero for these 3 species (i.e. H. sciurus $0.002 \pm$ 0.045 ; L. apodus $0.3 \pm 2.2 ;$ L. mahogani $0.19 \pm 1.2$ ), the relatively high densities ( $>1.6$ adults $100 \mathrm{~m}^{-2}$ ) of these species on reefs some distance away from seagrassmangrove habitats may be better explained by the suggested migration of adults and subadults from seagrass-mangrove habitats towards these reefs along the coastline instead of local recruitment to the reef. Compared with Curaçao (Dorenbosch et al. 2004), Aruba is smaller, and the semi-enclosed lagoon containing seagrass beds and mangroves has various entrances to the coral reef, resulting in shorter distances fishes have to bridge in order to reach reefs located farther away from these juvenile habitats. The density distribution of Scarus guacamaia also supports this pattern. This species is thought to depend heavily on mangroves (Mumby et al. 2004, Dorenbosch et al. 2006) and, in the present study, juveniles were exclusively observed in mangroves while the highest den- sity on coral reefs was observed on exposed east reefs, suggesting migration of adults along the coast. Migration along the coast has also been suggested by Halpern (2004) as a possible explanation for high fish densities of $L$. apodus on coral reefs away from mangroves on the Virgin islands.

The natural spatial arrangement of coral reef, seagrass and mangrove habitats along the coast of the island resulted in a pseudo-replicated design of study sites (i.e. an unbalanced spatial arrangement of seagrass and mangrove habitats on the southeastern side of the island and of different types of coral reefs on the entire island). This may have confounded the conclusions on the connectivity between fish assemblages in seagrass-mangrove habitats and on coral reefs. However, based on all previous work in this field and highly similar results on Curaçao (Nagelkerken et al. 2000, 2002, Dorenbosch et al. 2004), habitat configuration shaping connectivity between the habitats is a more likely explanation. The suggested migration along the coast and/or the possible local recruitment on coral reefs indicate that some coral reef sites are probably more attractive fish habitats than others. Environmental variables such as coral cover or water depth may influence the attractiveness of a coral reef site for particular species. Hard coral cover had a significant effect on the density of various species, such as species of Haemulidae and Lutjanidae, which may have been due to the shelter or feeding opportunities offered by a coral reef site. As a result of their location on the eastern point of the island, exposed east reefs are subject to water currents straight from the ocean that may result in different environmental conditions than on the other reef types. This may result in an attractive adult fish habitat and influence species richness and density of the total assemblage or individual species (Dominici-Arosemena \& Wolff 2005).

\section{CONCLUSIONS}

The results of the present study support the following conclusions: (1) Differences in the fish assemblage composition, species richness, fish density and fish size in seagrass-mangrove as well as coral reef habitats appears to be related to the configuration of seagrassmangrove habitats in relation to the coral reef. This may possibly be explained by habitat accessibility and habitat complexity, which may affect short distance migration by reef-associated fishes and/or predators, ontogenetic migration over larger distances, and shelter possibilities of a habitat with respect to predation. (2) The occurrence of coral reef fish species using seagrassmangrove habitats as a juvenile habitat appeared to be related to the presence of seagrass-mangrove habitats 
at island level, resulting in the absence or low densities of most of these species on isolated reefs. (3) At a smaller scale, this effect is possibly confounded by local recruitment of some species on the reef and long distance migration along the coast by other species. The results of this study suggest that, rather than merely type of habitat, the configuration of habitats in the marine landscape should also be taken into account to achieve an understanding of the function of seagrasses and mangroves as a juvenile habitat and habitat connectivity. This can shape and increase the efficiency of management actions related to marine protected areas.

Acknowledgements. This study was funded by the Department of Agriculture and Fisheries (DAF) of the island of Aruba, and by Nuffic through the ENVIRONS - MHO programme. The study was partly supported by a Vidi fellowship from the Netherlands Organisation for Scientific Research (NWO) to I.N. 'Fly and Dive Aruba' provided all diving facilities. G. Atsma and J. Bosveld assisted in the collection of field data. We thank the staff and personnel of DAF and 'Fly and Dive Aruba' for their logistic support and facilities. F. Franken, P. Portier and G. Rasmijn provided important logistic support during the field research. W. Lemmens and T. de Boo of the Department of Epidemiology and Biostatistics, Radboud University Nijmegen assisted with the statistics. This is Publication No. 400 of the Centre for Wetland Ecology.

\section{LITERATURE CITED}

Anonymous (1953) Atlas of surface currents. Central American waters. Hydrographic Office, United States Navy, Washington DC

Beck MW, Heck KL, Able KW, Childers DL and 9 others (2001) The identification, conservation, and management of estuarine and marine nurseries for fish and invertebrates. BioScience 51:633-641

Beets J (1997) Effects of a predatory fish on the recruitment and abundance of Caribbean coral reef fishes. Mar Ecol Prog Ser 148:11-21

Beets J, Muehlstein L, Haught K, Schmitges H (2003) Habitat connectivity in coastal environments: patterns and movements of Caribbean coral reef fishes with emphasis on bluestriped grunt, Haemulon sciurus. Gulf Caribb Res 14: 29-42

Belmaker J, Shashar N, Ziv Y (2005) Effects of small-scale isolation and predation on fish diversity on experimental reefs. Mar Ecol Prog Ser 289:273-283

Blaber SJM (2000) Tropical estuarine fishes: ecology, exploitation and conservation. Blackwell Science, Oxford

Bullard SG, Hay ME (2002) Plankton tethering to assess spatial patterns of predation risk over a coral reef and seagrass bed. Mar Ecol Prog Ser 225:17-28

Chitaro PM, Usseglio P, Sale P (2005) Variation in fish density, assemblage composition and relative rates of predation among mangroves, seagrass and coral reef habitats. Environ Biol Fish 72:175-187

Cocheret de la Morinière E, Pollux BJA, Nagelkerken I, van der Velde G (2002) Post-settlement life cycle migration patterns and habitat preference of coral reef fish that use seagrass and mangrove habitats as nurseries. Estuar Coast Shelf Sci 55:309-321
Cocheret de la Morinière E, Nagelkerken I, van der Meij $\mathrm{H}_{\text {, }}$ van der Velde G (2004) What attracts juvenile coral reef fish to mangroves: habitat complexity or shade? Mar Biol 144: 139-145

Dahlgren CP, Eggleston DB (2000) Ecological processes underlying ontogenetic habitat shifts in a coral reef fish. Ecology 81:2227-2240

Dominici-Arosemena A, Wolff M (2005) Reef fish community structure in Bocas del Toro (Caribbean, Panama): Gradients in habitat complexity and exposure. Caribb J Sci 41: 613-637

Dorenbosch M, van Riel MC, Nagelkerken I, van der Velde G (2004) The relationship of reef fish densities to the proximity of mangrove and seagrass nurseries. Estuar Coast Shelf Sci 60:37-48

Dorenbosch M, Grol MGG, Christianen MJA, Nagelkerken I, van der Velde G (2005) Indo-Pacific seagrass beds and mangroves contribute to fish density and diversity on adjacent coral reefs. Mar Ecol Prog Ser 302:63-76

Dorenbosch M, Grol MGG, Nagelkerken I, van der Velde G (2006) Seagrass beds and mangroves as nurseries for the threatened Indo-Pacific Humphead wrasse, Cheilinus undulatus and Caribbean Rainbow parrotfish, Scarus guacamaia. Biol Conserv 129:277-282

Eggleston DB, Dahlgren CP, Johnson EG (2004) Fish density, diversity, and size-structure within multiple back-reef habitats of Key West National Wildlife Refuge. Bull Mar Sci 75:175-204

Garcia-Charton JA, Perez-Ruzafa A (1999) Ecological heterogeneity and the evaluation of the effects of marine reserves. Fish Res 42:1-20

Gratwicke B, Speight MR (2005) The relationship between fish species richness, abundance and habitat complexity in a range of shallow tropical marine habitats. J Fish Biol 66: $650-667$

Grober-Dunsmore R, Frazer TK, Beets J, Funicelli N, Zwick PD (2004) The significance of adjacent habitats on reef fish assemblage structure: Are relationships detectable at a landscape scale? Proc Gulf Caribb Fish Inst 55:713-734

de Haan D, Zaneveld JS (1959) Some notes on tides in Annabaai Harbour, Curaçao, Netherlands Antilles. Bull Mar Sci Gulf Caribb 9:224-236

Halpern BS (2004) Are mangroves a limiting resource for two coral reef fishes? Mar Ecol Prog Ser 272:93-98

Heck KL, Hays G, Orth RJ (2003) Critical evaluation of the nursery role hypothesis for seagrass meadows. Mar Ecol Prog Ser 253:123-136

Hyndes GA, Kendrick AJ, MacArthur LD (2003) Differences in the species- and size-composition of fish assemblages in three distinct seagrass habitats with differing plant and meadow structure. Mar Biol 142:1195-1206

Jongman RHG, ter Braak CJF, van Tongeren OFR (1995) Data analysis in community and landscape ecology. Cambridge University Press, Cambridge

Kaunda-Arara B, Rose GA (2004) Out-migration of tagged fishes from marine reef National Parks to fisheries in coastal Kenya. Environ Biol Fish 70:363-372

Laegdsgaard P, Johnson C (2001) Why do juvenile fish utilise mangrove habitats? J Exp Mar Biol Ecol 257:229-253

Lecchini D, Galzin R (2005) Spatial repartition and ontogenetic shifts in habitat use by coral reef fishes (Moorea, French Polynesia). Mar Biol 147:47-58

Mazerolle MJ, Drolet B, Desrochers A (2001) Small-mammal responses to peat mining of southeastern Canandian bogs. Can J Zool 79:296-302

McAleece N (1997) BioDiversity Pro Beta 2. The Natural History Museum, London 
Mumby PJ, Edwards AJ, Arias-Gonzalez JE, Lindeman PG and 7 others (2004) Mangroves enhance the biomass of coral reef fish communities in the Caribbean. Nature 427: 533-536

Nagelkerken I, van der Velde G (2002) Do non-estuarine mangroves harbour higher densities of juvenile fish than adjacent shallow-water and coral reef habitats in Curaçao (Netherlands Antilles)? Mar Ecol Prog Ser 245:191-204

Nagelkerken I, Dorenbosch M, Verberk WCEP, Cocheret de la Morinière E, van der Velde G (2000) Importance of shallow-water biotopes of a Caribbean bay for juvenile coral reef fishes: patterns in biotope association, community structure and spatial distribution. Mar Ecol Prog Ser 202: 175-192

Nagelkerken I, Roberts CM, van der Velde G, Dorenbosch M, van Riel MC, Cocheret de la Morinière $\mathrm{E}$, Nienhuis $\mathrm{PH}$ (2002) How important are mangroves and seagrass beds for coral-reef fish? The nursery hypothesis tested on an island scale. Mar Ecol Prog Ser 244:299-305

Nanami A, Nishihira A (2001) Survival rates of juvenile coral reef fishes differ between patchy and continuous habitats. Bull Mar Sci 69:1209-1221

Parrish JD (1989) Fish communities of interacting shallow

Editorial responsibility: Howard Browman (Associate Editorin-Chief), Storebø, Norway water habitats in tropical oceanic regions. Mar Ecol Prog Ser 58:143-160

Pedan A (2006) Analysis of count data using the SAS system. Vasca, Tewksbury, MA (Also available at: www2.sas.com/ proceedings/sagi26/p247-26.pdf

Pittman SJ, McAlpine CA, Pittman KM (2004) Linking fish and prawns to their environment: a hierarchical landscape approach. Mar Ecol Prog Ser 283:233-254

SAS Institute (1993) SAS/STATTM software: the GENMOD procedure. Tech Rep, SAS Institute, Cary, NC

Serafy JE, Faunce CH, Lorenz JJ (2003) Mangrove shoreline fishes of Biscayne Bay, Florida. Bull Mar Sci 72:161-180

Shulman MJ (1985) Recruitment of coral reef fishes: effects of distribution of predators and shelter. Ecology 66: 1056-1066

Tulevech SM, Recksiek CW (1994) Acoustic tracking of adult white grunt, Haemulon plumieri, in Puerto Rico and Florida. Fish Res 19:301-319

Verweij MC, Nagelkerken I, de Graaff D, Peeters M, Bakker EJ, van der Velde G (2006) Structure, food and shade attract juvenile coral reef fish to mangrove and seagrass habitats: a field experiment. Mar Ecol Prog Ser 306: $257-268$

Submitted: October 25, 2005; Accepted: July 23, 2006 Proofs received from author(s): March 5, 2007 